
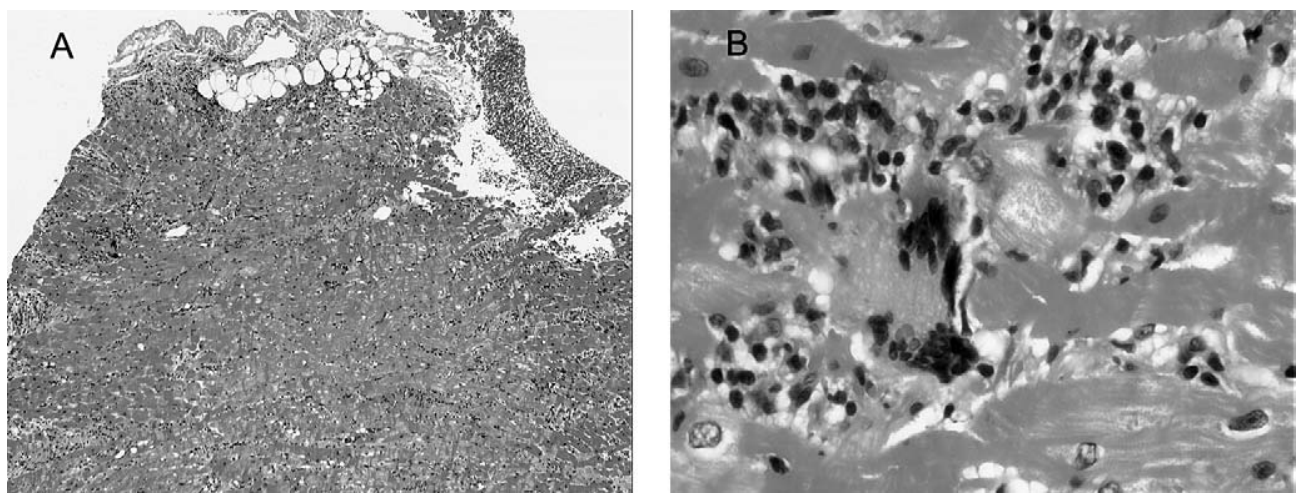

Figure 1. A, Histologic examination showing widespread or multifocal serpiginous necrosis with multinucleated giant cells and mixed inflammatory infiltrate composed of lymphocytes and few eosinophils. B, Multinucleated giant cells seen adjacent to necrosis.

\section{References}

1. Cooper LT Jr, Berry GJ, Shabetai R. Idiopathic giant-cell myocarditisnatural history and treatment. Multicenter Giant Cell Myocarditis Study Group Investigators. N Engl J Med. 1997;336:1860-6.

2. Marelli D, Kermani R, Bresson J, Fishbein MC, Hamilton M, Moriguchi J, et al. Support with the BVS 5000 assist device during treatment of acute giant-cell myocarditis. Tex Heart Inst J. 2003;30:50-6.
3. Brilakis ES, Olson LJ, Berry GJ, Daly RC, Loisance D, Zucker M, et al. Survival outcomes of patients with giant cell myocarditis bridged by ventricular assist devices. ASAIO J. 2000;46:569-72.

4. Stoica SC, Goddard M, Tsui S, Dunning J, McNeil K, Parameshwar J, et al. Ventricular assist surprise: giant cell myocarditis or sarcoidosis? J Thorac Cardiovasc Surg. 2003;126:2072-4.

5. Frustaci A, Chimenti C, Pieroni M, Gentiloni N. Giant cell myocarditis responding to immunosuppressive therapy. Chest. 2000;117:905-7.

\title{
Ascending-descending aortic bypass with the aid of a heart-lifting device
}

Alejandro Aris, MD, PhD, ${ }^{a}$ Javier Cobiella, MD, ${ }^{a}$ Maria Luz Maestre, MD, ${ }^{\mathrm{b}}$ and Maria Teresa Subirana, MD, ${ }^{\mathrm{C}}$ Barcelona, Spain

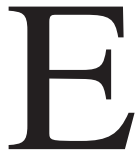
xtra-anatomic aortic bypass from the ascending to the descending aorta is an alternative for repair of complex aortic anomalies. We describe a case of repair of recoarctation of the aorta through a median sternotomy and posterior pericardial approach in which surgical exposure of the

From the Departments of Cardiac Surgery, ${ }^{\mathrm{a}}$ Anesthesia, ${ }^{\mathrm{b}}$ and Cardiology, Hospital de la Santa Creu i Sant Pau, Barcelona, Spain.

Received for publication April 7, 2006; accepted for publication April 20, 2006.

Address for reprints: Alejandro Aris, MD, PhD, Department of Cardiac Surgery, Hospital de la Santa Creu i Sant Pau, Avenida San A. M. Claret 167, 08025 Barcelona, Spain (E-mail: aaris@santpau.es).

J Thorac Cardiovasc Surg 2006;132:433-4

$0022-5223 / \$ 32.00$

Copyright $\odot 2006$ by The American Association for Thoracic Surgery doi:10.1016/j.jtcvs.2006.04.017 retrocardiac aorta was obtained by means of a heartlifting device (Starfish 2; Medtronic, Inc, Minneapolis, Minn) commonly used in off-pump coronary artery bypass grafting.

\section{Clinical Summary}

A 70-year-old man was seen with dyspnea on exertion and intermittent claudication. He was hypertensive, in atrial fibrillation, and taking oral anticoagulants. His medical history included repair of aortic coarctation (end-to-end anastomosis) 29 years previously. Echocardiography showed left ventricular hypertrophy with moderately depressed left ventricular function (ejection fraction 40\%). He underwent aortic angiography, which confirmed the diagnosis of aortic recoarctation with a gradient of $48 \mathrm{~mm} \mathrm{Hg}$ across the coarctation. The thoracic descending aorta was tortuous (Figure 1).

In view of the patient's age and left ventricular impairment, it was decided that an extra-anatomic repair would be less harmful 
than a standard approach for recoarctation. He underwent reoperation through a median sternotomy. Cardiopulmonary bypass (aortic and right atrial cannulation) was instituted with a left ventricular vent through the right superior pulmonary vein. With the heart beating, the posterior pericardium was opened. Because of the tortuosity of the aorta, this was found lying on the right side of the spine. To provide a good, constant exposure, a suction heart-lifting system (Starfish 2) was applied to the apex of the heart, which was retracted cephalad. The view of the operative field was excellent (Figure 2). The esophagus was retracted, and the aorta was surrounded with tapes and partially clamped. A 20-mm vascular graft (Hemashield Platinum; Boston Scientific Medi-tech, Wayne, NJ) was anastomosed to the descending aorta. After repositioning of the heart, the graft was routed around the left margin of the heart, anterior to the main pulmonary artery, and anastomosed to the ascending aorta. The patient was weaned from cardiopulmonary bypass and made an uneventful recovery. He is symptom free and normotensive, with low doses of $\beta$-blockers, 6 months after the procedure.

\section{Discussion}

Vijayanagar and colleagues ${ }^{1}$ reported a novel extra-anatomic surgical approach for repair of aortic coarctation through a median sternotomy. Procedures of bypass from the ascending aorta to the abdominal aorta $^{2}$ and combined left thoracotomy and median sternotomy ${ }^{3}$ have also been described. However, the posterior pericardial approach limits the procedure to a single incision, and it is especially convenient when concomitant cardiac procedures must be performed. Favorable long-term results as late as 22 years have recently been reported. ${ }^{4}$

In our case, we chose this approach because the patient had mild impairment of the left ventricular function, which precluded total aortic clamping proximal to the coarctation. We believed that cardiopulmonary bypass with a vented, beating heart would be the less deleterious of the available procedures. Operating on the recoarctation area could have been hazardous; we have previously encountered

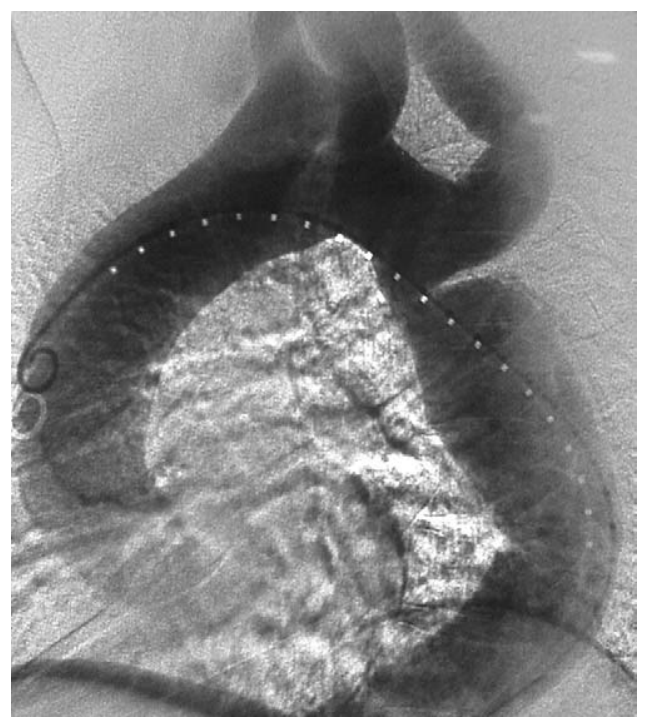

Figure 1. Aortogram shows aortic recoarctation with tortuous descending aorta.

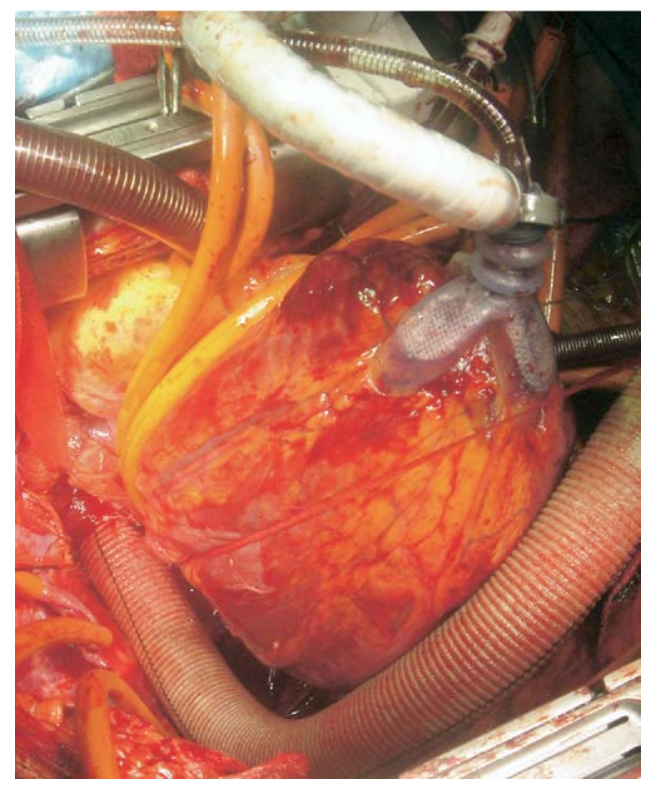

Figure 2. View of operative field from assistant's side. Heart is retracted cephalad with Starfish 2, and graft is anastomosed to descending aorta. Note marked displacement of the aorta toward right.

severe calcification of the distal aortic arch and left subclavian artery when repairing an aortic coarctation in patients older than 50 years. ${ }^{5}$

Most groups favor positioning the graft in the right side of the pericardium, either posterior or anterior to the inferior vena cava. In our case, however, the aorta was extremely displaced to the right, and directing the graft toward that side would have resulted in a position prone to kinking.

The use of a suction heart-lifting device provided an excellent exposure with steady retraction of the heart without damaging it, avoiding crowding of the operative field with the hand of an assistant during the distal anastomosis. It is possible that with the aid of this device the procedure can be performed off pump in selected cases.

\section{References}

1. Vijayanagar R, Natarajan P, Eckstein PF, Bognolo DA, Toole JC. Aortic valvular insufficiency and postductal aortic coarctation in the adult: combined surgical management through median sternotomy-a new surgical approach. J Thorac Cardiovasc Surg. 1980;79: 266-8.

2. Wukasch DC, Cooley DA, Sandiford FM, Nappi G, Reul GJ Jr. Ascending aorta-abdominal aorta bypass: indications, technique and report of 12 patients. Ann Thorac Surg. 1984;37:261-3.

3. Jacob T, Cobanoglu A, Starr A. Late results of ascending aortadescending aorta bypass graft for recurrent coarctation of the aorta. J Thorac Cardiovasc Surg. 1998;95:782-7.

4. Almeida de Oliveira S, Lisboa LA, Dallan LA, Abreu F CA, Rochitte $\mathrm{CE}$, et al. Extraanatomic aortic bypass for repair of aortic arch coarctation via sternotomy. Midterm clinical and magnetic resonance imaging results. Ann Thorac Surg. 2003;76:1962-6.

5. Aris A, Subirana MT, Ferres P, Torner-Soler M. Repair of aortic coarctation in patients more than 50 years of age. Ann Thorac Surg. 1999;67:1376-9. 